\title{
Effect of Local Market and IT Infrastructure of Emerging Markets on American's MNCs
}

\author{
Dr. Pooya Sabetfar (Corresponding author) \\ Faculty of Economics and Management, University Putra Malaysia \\ 43400 Serdang, Selangor, Malaysia \\ Tel: 60-17-389-1012Ｅ-mail: psabetfar@yahoo.com
}

Dr. Cheng Fan Fah, Associate Professor

Faculty of Economics and Management, University Putra Malaysia

43400 Serdang, Selangor, Malaysia

Tel: 60-16-696-5840Ｅ-mail: chengfanfah@yahoo.com

Dr. Reza Hajimohammadi

Faculty of Education, University Putra Malaysia

43400 Serdang, Selangor, Malaysia

Tel: 60-17-629-4700 E-mail:reza_hajimohammadi@yahoo.com

Received: December 5, 2010

Accepted: January 4, 2011

doi:10.5539/ijef.v3n4p251

\begin{abstract}
Brazil, India, and China have been emerged as the new markets for multinational corporations (MNCs).The opportunities for Multinational Corporations (MNCs) in other emerging markets are infinite, but before a MNC decides to invest, there are some questions that they should be asked by themselves about IT infrastructure, cultural issues, distribution networks and business model. With considering the large middle class, vast resources, privatization and economic reforms, these countries now offer a great deal of investment opportunities. This paper has quantitative analysis that studies the difference between local market from cultural issues and IT infrastructure of these emerging markets from the prospect for investing American companies in the countries. For Distinguishing between low, medium and high IT infrastructure of the countries, we used the number of fixed line, mobile phone subscribers and internet users. According to the results, Brazil is the best choice for American multinational firms from local market and IT infrastructure point of view, India is lowest class and China is the middle class emerging market between these host countries.
\end{abstract}

Keywords: Multinational Corporations, IT infrastructure, Cultural issues and Emerging markets

\section{Introduction}

Multinationals have played an important role in globalization. The economic function of multinational corporations (MNCs) is to direct fiscal and financial capital to countries with capital scarcities. Consequently, wealth is created, which yields novel jobs straight and via "crowding-in" effects. Besides, new tax revenues arise out of MNC made income, permitting developing countries to progress their infrastructures and to reinforce their human capital. Through improving the effectiveness of capital flows, MNCs decrease world poverty ranks and present an affirmative externality. For the meantime, multinational companies are at the other end of the variety. These kinds of companies permit their foreign subsidiaries "free-reign". Based on Fons Trompenaars (1998), writer of Riding the Waves of Culture, based management consulting firm, well-known as the United Nations, the MNCs construction is the "wave of the future for truly successful international ventures" (Hickins, 1998). MNSc conclude which processes can be practical generally and which should be determined upon locally. They can efficiently settle cultural and infrastructure distinctions and concentrates on what they have in general to come at clarifications.

Emerging markets are countries that need MNCs for developing. With regard to the international achievement and mobility, emerging markets and sometimes regions within countries must compete with each other to have MNCs. To compete, countries and regional political districts offer incentives to MNCs such as tax breaks, pledges of 
governmental assistance or improved infrastructure, or lax environmental and labor standards. Broadly defined, an emerging market is a country which makes an effort to change and improve its economy with the goal of raising its performance to that of the world's more advanced nations. Emerging markets are not necessarily small or poor. China, for example, is considered an emerging market since it has vast resources and a population of more than a billion people. It has launched satellites into space and has a rather large army. Brazil is also an emerging market since it has Latin America's largest economy. Its government has effectively insulated its currency, the real from the aftershocks of the Asian currency crisis. India is also an emerging market. Based on purchasing power parity, India is the fifth largest economy in the world. It has the third largest GDP in the entire continent of Asia and is the second largest among emerging nations (IMF, 2006). Economic times state that "India will be emerged as the second largest economy throughout the world by the year 2050" (BRIC's Research paper, 2007).

On emerging markets quest for growth, American multinational firms will have no choice but considering the emerging markets of India, Brazil and China. These emerging markets should be important from American's MNCs point of view. These Emerging markets, including Brazil, India and China, comprise 60 percent of the world's population. Presently it is estimated that there are over 600 million consumers in emerging markets who have an annual income of US $\$ 7500$, or more. Forecasters expect that within the next ten years, the emerging economies will add another 500 million consumers to this total (Daniels and Cannice, 2004). The world economy grew 5.2\% in 2007 powered by growth in China (11\%), India (9\%) and Russia (8\%). The Emerging Markets, led by the giants of China, India, Russia and Brazil (the BRIC countries) had been posting 7\%-10\% grow rates for years (Bulletin of World Bank, 2007). So, considering the large middle class, population, vast resources, privatization, and economic reforms, these countries now offer a great deal of investment opportunities for American's multinational companies. The opportunities for American Multinational Corporations (MNCs) in the emerging markets are infinite, but before MNCs decide to invest in the three countries, there are some questions that they should ask themselves: What are the key characteristics of the distribution networks in these markets, and how are the networks evolving? What are the cultural issues in these markets and which one is near to them? Which is the highest to lowest class market in these countries from point of view of IT infrastructure and cultural issues?

The IT infrastructure encompasses a set of computer related capabilities that provide the foundation for enabling other business processes (McKay and Brockway, 1989). IT resources such as hardware platforms, data, networks and communication technologies like telephone line, internet are integral parts of the IT infrastructure. They aim at supporting core business activities and providing a means for integrating business processes (Green, 1995). Also considered part of the IT infrastructure capabilities are the managerial and support activities that shape and bind together the more tangible IT resources (Broadbent, Weill and Neo, 1996). IT infrastructure is a major business resource and is increasingly being recognized for its contribution to the achievement of sustainable competitive advantage (Davenport and Linden, 1994).

The way a multinational company identifies itself tends to give a strong indication of how effectively it is able to resolve infrastructure problem and cultural issues. A strategy for modeling the impact of infrastructure on growth and firm location decisions has been to focus on the trade facilitation aspects of infrastructure. This idea, developed in Martin (1999), raises the point that quite often the effect of infrastructure development is not captured in its contribution to production, but rather in its effectiveness in lowering trade and transaction costs. In the process of lowering transaction costs, infrastructure development will affect industrial location across countries and ultimately affect aggregate GDP growth. Empirically, Limao and Venables (2001) find support for the idea that infrastructure lowers trade costs and leads to greater volumes of trade. The importance of infrastructure for the growth of economies and the determination of industrial location are subjects that have been extensively examined over the course of the past 15 years. But little attention has been paid empirically to the channels through which infrastructure, firm location, and domestic productivity interact. Theoretical models [see for example Martin (1999), Haughwout (2002), Baldwin, Forslid, Martin, Ottaviano and Nicoud, (2003), and Kellenberg (2003, a)] have shown that public inputs such as infrastructure can have significant impacts on the marginal productivity of factors of production, create agglomerate externalities, lower the costs of production, facilitate knowledge spillover, and attract foreign investment. This paper is organized as follows. Next section summarizes the evidence on multinational corporations; third section explains the method and research deigns; fourth section includes discussion on findings and fifth section explains the conclusion.

\section{Literature review}

The power of the MNCs has been described by writers such as Dunning (1974), Wilczynsky (1976), Curzon and Curzon (1977), Faundez and Picciotto (1978), Lall (1983), and Neghandhi (1985). According to Takayama (1985) the lack of knowledge about internal labor management policies of MNCs is one reason most researchers on industrial relations in MNCs have had inconclusive findings. He stresses the need for a study of the internal 
processes within a cross-cultural perspective. The study of Thurley, Reitsperger, Trevor, and Worm, (1980) is important because it examined the development of personnel management practices among Japanese enterprises in Britain. King and Flor (2008) study the impact of a multinational corporations' (MNC) global strategic orientation on global IT infrastructure. It was developed and employed global integration and a global strategy was actually implemented as a mediator. The results showed that the firms that pursued a globally oriented strategy actually enacted these strategies as indicated by a wide variety of resource flows across national units.

\section{Methodology and Research Design}

This paper has quantitative analysis that studies the difference between local market, cultural issues and IT infrastructure of these emerging markets from the prospect of American MNCs for investing. The sample includes markets of three countries: Brazil, China and India. Most previous studies use two-country framework and can be solved analytically. The three-country world adds realism at the expense of tractability. IT infrastructure includes different parts which, in this research studies the number of telephone lines and internet users. Distinguishing between low, medium and high telecommunications in countries this study used the same classification as Roller and Waverman, (2001). According to this classification, an observation with less than 20 main lines per 100 people is classified as 'low' telecommunications. An observation between 20 and 40 main lines per 100 people is classified as 'medium' telecommunications. Finally, an observation with 40 or greater main lines per 100 people is classified as 'high' telecommunications. Our data covers from 1997-2007 and obtained from International financial statistics (IMF), United nations Conference on Trade and Development (UNCTAD), World Bank Bulletin and Department of Statistic of U.S.A.

\section{Discussion on Findings}

\subsection{Brazil}

Brazil is an attraction for multinational firms because it is the tenth largest economy in the world. It has the population of 189.3 million inhabitants and a GDP over \$1.1 U.S. trillion in 2007 (World Bank, 2007). It is a highly diversified economy with wide variations in levels of development. Market liberalization and economic stabilization has significantly attracted investors due to significantly enhanced growth prospects. The United States and European Union are the largest foreign investors in Brazil, accounting for almost U.S $\$ 30$ billion, or $44 \%$ of total foreign investment. Foreign direct investment has increased from less than U.S \$1 billion in 1993 to an estimated U.S \$23 billion in the end of 2008 (U.S Department of Statistics, 2009).

On the contrary, Brazil was not always prosperous and attractive to investors. From 1978-1982 Brazil borrowed $\$ 63.4$ billion, well over half of its total grosses foreign debt, in a frenzied and eventually useless attempt to avoid default. Almost all of this money did not even enter Brazil, but stayed with the foreign banks (\$60.9 billion). In 1994 Brazil was recorded as having the third world's largest foreign debt of $\$ 152$ billion and had the region's highest inflation (Green, 1995). The main reason for this high inflation is the public sector deficit. Severe political constraints have also helped tie the government's hands on inflation. The Brazilian elite have a long-standing aversion to paying taxes, while a series of weak governments has repeatedly placed short-term considerations before long-term economic well-being. In mid 1994 then Finance Minister Fernando Henrique Cardoso launched Brazil's most successful economic stabilization program, the Plano Real in July 1994. It curbed inflation, which had reached an annual level of nearly $5000 \%$ at the end of 1993; it has since dropped to its lowest level in over 40 years to fewer than $4 \%$ in September 2007. Brazil has accomplished to this plan through a strong exchange rate, tight monetary policies, trade liberalization and privatization.

This government models greatly facilitated Brazil's business structure. The plan was a spectacular initial success, prevailing international acclaim and winning Cardoso the presidency in October 1994. The Plano Real has raised the income of poor Brazilians, but Brazil continues to have one of the world's most inequitable distributions of income. However in early 1995, Cardoso devalued the Real and restarted some import barriers to try to avert a Mexico-style crisis (Green, 1995).

The United States continues to be the top supplier to Brazil, accounting for almost one-third of total Brazilian imports, Brazil's telecommunications and informatics markets offer tremendous potential for U.S business, both for equipment manufacturers and service providers. Telecommunications represents a $\$ 3$ billion market. U.S. companies are currently allowed limited participation in this sector and are taking advantage of opportunities to provide private networks and equipment. Similarly, Brazil opened its rapidly growing informatics market to imports by ending its market reserve policies. U.S exports of computers, peripherals and office equipment have almost doubled since 1991 as U.S and Brazilian companies have established joint ventures and representational agreements. Greater telecommunications infrastructure can have a direct productive effect on domestic and multinational firms in the country by facilitating connecting amongst workers and knowledge spillover through more efficient 
communication. However, an increase in telecommunications infrastructure also increases the ability of multinational firms to communicate with customers and access markets, thus lowering the transaction costs associated with trade (Freund and Weinhold, 2003) then the direct transaction cost effect of IT infrastructure on multinational firms is to decrease production by multinational firms in Brazil. Telecommunication data is measured as the total stock of telephone mainline and internet user in a country increase. Based on classification as R and W (Roller and Waverman, 2001), we discuss about IT infrastructure in Brazil.

Table 1 shows fixed line and mobile phone subscribers and Internet Users as the two important parts for IT infrastructure. Since the numbers of users of fix telephone line and mobile phone subscribers are more than 40 users per 100 people, Brazil, from 2002, has high IT infrastructure from fix telephone line and mobile phone subscriber point of view. But the numbers of internet users are between 20 and 40 per 100 people. Therefore, internet user in Brazil has medium from 2006. It is clear that IT infrastructure has high-quality in Brazil and that can be good reason for answering the research question about that USA can choose Brazil as the alternative for its MNC with respect to the good IT infrastructure and nearly local market. Considering the good IT infrastructure, international activity in Brazil is a superior situation for USA and Brazil's telecommunications and informatics markets offer remarkable potential for U.S business.

Also Brazil's energy part proposes important potential for U.S equipment and technology. Regarding market liberalization, Brazil's identification of it's requiring for larger investment in energy development is prompting significant deliberations. The occasions for multinational firms have been restricted by constitutional restrictions and legislative requirements, however; current legislation and constant deliberations among administration leaders and the private part hold guarantee for the future. U.S. equipment producers are promoted to exploit opportunities that previously existed and are expected to develop as interior demand makes this part's expansion.

State and civic administrations in Brazil have carried out chief environmental and infrastructure schemes with the fiscal support of multilateral subsidy institutions such as the Inter-American Development Bank. The Sao Paulo is increasing the Tiete-Parana channel, effectively involving the richest grain-producing area of Brazil with the rest of the country and with Argentina and Uruguay. Sao Paolo, Rio de Janeiro and Porto Alegre are also enterprising immense environmental water clean-up schemes in which with U.S. technology and products could be greatly competitive. Since these projects are funded by multilateral banks, U.S companies are guaranteed a fair occasion to compete via international bids (Jennings, 1994). The business situation in Brazil is expected to carry on improving over the long-term, but short-term proceedings should be observed by multinational businesses interested in the market (Green, 1995). For multinational firms in Brazil the sectors that are most promising contain electronic components, industrial and agricultural chemicals, automotive parts, medical and capital equipment (Jennings, 1994). U.S exports of certain services are as well extremely competitive in Brazil, containing franchising and travel/tourism services (see Table 1).

\subsection{India}

India alone has 1.1 billion people; almost $1.5 \%$ of the world's population (IFS-2007). It may be unbelievable from a western point of view, but India is the fifth largest economy in the world based on purchasing power. It ranks ahead of France, Italy, United Kingdom, and Russia (Janakay and Machure, 1998). With these startling numbers almost every MNC in the world is looking to invest in India. However, there have been economic and social barriers in the past that are currently beginning to be lifted.

India gained its independence from Britain 50 years ago. Janakay said that “...India developed a highly protected, semi-socialist autarky economy, vigorously fostering structural and bureaucratic impediments as well as a distrust of foreign business" (Janakay, 1998). The socialist ways of the past have moved aside for a democracy. The people of India that have been starved of consumer goods in the past are now hungry for more upscale goods from foreign countries. Indians, for example, will buy any product once, but brand switching is common. One survey found that "Indian consumers tried on average 6.2 brands of the same packaged-goods product in one year, compared with 2.0 for American consumers" (Prahalad, 1998). Indian consumers want to try out new goods. They have not had the chance in the past and they will try almost anything. A major problem in India is customer retention. Goods need to be tailored to the Indian consumer. MNCs need to be aware of the fact that they may not be able to offer the same product to consumers in foreign countries as they do in their home countries. It could be stressed enough that foreign investors need to understand the local customs and beliefs before trying to sell their products or services there.

The Indian middle class is extremely large. The emerging middle class is possibly larger than the entire population of the United States. The potential to make a profit is definitely in India, but their local traditions and customs are extremely different from American and European cultures and this can create many problems for corporations. In the past, there have been many multinational companies that have tried to invest in India and have failed because of 
local market. For example, Ford is trying to install a dealer network to sell cars in India. "To obtain a dealership, each prospective dealer is expected to invest a large amount of his own money and must undergo special training. In the long haul, Ford's approach may prove to be a major source of advantage to the company, but the cost in cash and managerial attention of building the dealer's network will be substantial" (Prahalad, 1998). The real profit in India is to be made by catering to the middle class.

Meanwhile, understanding the local market's customs is only a small portion of the equation. A major problem when dealing with emerging markets is that of distribution. The infrastructure in these countries, at best, is well below par with the rest of the world. It is impossible to sell goods to a consumer if you cannot deliver the goods to them. The lack of infrastructure can also be an opportunity for multinational companies. Problems with infrastructure include: "power demand shortfall, port traffic capacity mismatch, poor road conditions, low telephone and mobile penetration (18.6\% of the population). The importance of telephone lines is immense. These networks are being installed and the services delivered with the intent of developing the local economy and improving the citizen's standard of living. This, in turn, eventually creates an environment of increasing prosperity and consumption. The growing middle class will be the basis for a greater consumer market, which represents a very attractive export market for the rest of the world. Table 2 shows telephone line and internet user in India. Telephone line density from 2007 has medium situation with regard to the number of users. The number of telephone and mobile line is between 20 and 40 per 100 people. But internet user has low-grade. In 2007 only 18 from 100 people could use internet. Since the numbers of internet users are below 20 per 100 people, India has low-class in this part of IT infrastructure. India has a weak IT infrastructure and local market so it is a big problem for MNC of USA. One of the major indicators of how advanced the infrastructure of a country is the average density of telephone lines. The worldwide average is about $24 \%$ ( 24 lines per 100 people). The government of India and other emerging countries are implementing plans to privatize the telecommunications industry in order to obtain a modern network of telephone lines.

The rationale behind privatization is that private companies will probably install the lines quicker and more efficiently. The privatization of the power sector is also as important as telecommunications. In July 1994, Hazel O'Leary visited India in order to push for privatization. In response, "Several Memoranda of Understanding and joint ventures in the power sector have been signed between US and Indian firms following this visit". The megawatt capacity of India is only 480.5 in 2005 while the capacity in the United States is 810,964 (Prahalad, 1998). For multinational companies there are a lot of opportunities in India as well as the potential for extreme difficulties. They need to be aware of cultural difficulties as well as infrastructure problems for USA (see Table 2).

\subsection{China}

In 1978, the government of China began to embark on a major program of economic reform. Reforms included the formation of rural enterprises and private businesses, liberal foreign trade and investment policies, relaxed state price controls, investment in industrial production, and the education of its workforce. Post 1978 reforms also have given greater room for private ownership of production, which has led to the creation of more jobs, the development of consumer products, and the earning of hard currency through foreign trade. These reforms have given the national economy a flexibility and resiliency that it previously lacked. China's open-door policy toward foreign trade has been of the main factors behind its economic growth.

By welcoming foreign investment, foreign money has built factories, created jobs, linked China to foreign markets, and led to important transfers of technology. China has also experienced strong export growth, which has fueled productivity growth in domestic industries. China's extremely high population of 1.3 billion is another factor which makes the country an attractive opportunity for multinational firms (World Bank, 2007). The gradual opening of China's economy, as well as the recent strength in new growth markets like India and Brazil, present American businesses with a multitude of new opportunities. However, one major obstacle for U.S. business ventures has been a lack of cultural alignment. Differences in culture can lead to miscommunications, employee resentment, and poor public relations. The fact that foreign investment is slowing does not bode well for China's economy at this time. The Chinese Government has pledged to spend hundreds of billions of dollars on infrastructure in several years. The money needed for these programs is now much less likely to come China's way. The Chinese program for developing infrastructure also include telecommunication and this program has a positive and significant point to the American firms for investing in China. Road, telecommunication and internet infrastructures connect countries leads to more bilateral exports in both directions by lowering the transport costs of trade. Table 3 shows that from 2003 the number of fixed line and mobile subscribers are more than 40 per 100 people. Therefore, in China fixed line and mobile phone classified as high telecommunication from 2003. But, on internet users, it has been classified as low telecommunication with regard to the number of internet users below 20 per 100 people. Table 3 shows IT 
infrastructure in China from 1997-2007. Chinese telecommunication, real state, water industry seem good opportunities for American MNCs for investing (See Table3).

\section{Conclusion}

The role of infrastructure for increasing productivity, lowering trade costs, and influencing firm location decisions have become increasingly important issues for developed and developing countries alike. Here, it is shown that infrastructure projects that increase domestic productivity in a country will tend to favor domestic firms in that country, generate more exports, and attract multinational affiliate producers from abroad. Infrastructure development that is effective in lowering trade costs will tend to favor domestic firms in countries and lead to more bilateral exports in directions and fewer multinational affiliate producers. Brazil is the best choice for American multinational firms from local market and IT infrastructure point of view, India is lowest class and China is the middle class emerging market between these host countries. Obviously there is definitely a potential in the emerging markets of Brazil, India, and China. What a MNC needs to do is to thoroughly research each individual country. The MNC needs to find out everything possible about the local culture and local market. They need to find out everything from eating habits to which local celebrities are. Further, they need to capitalize on this research. A company will have to change their corporate mindset to compete in an almost totally different world. If the research is done thoroughly and implemented correctly, investment in emerging markets has the potential to be extremely profitable. Given the unlimited growth opportunity factors, the reasons for multinational firms to invest seem self-evident.

\section{References}

Baldwin, Richard, Rikard Forslid, Philippe Martin, Gianmarco Ottaviano \& Frederic Robert-Nicoud. (2003). Economic Geography and Public Policy. Princeton University Press, New Jersey.

BRIC. (2007). research paper. http://en.wikipedia.org/wiki/BRIC.

Broadbent M, Weill P, O'Brien T, Neo BS. (1996). Firm context and patterns of IT infrastructure capability. Proceedings of the $7^{\text {th }}$ international conference on information systems (ICIS). p. 174-94.

Curzon, G. \& Curzon, V.(1977). The Multinational Enterprise in a Hostile World. (eds.). Macmillan Press, London.

Daniels. J.D. \& M.V. Cannice. (2004). Interview studies in international business research. In: R. MarschanPiekkari \& C. Welch, Editors, Handbook of qualitative research methods for international business. Cheltenham/Northampton, pp. 85-206.

Davenport R \& Linden J. (1994). Information management infrastructure: the new competitive weapon. Proceedings of the 27th annual Hawaii international conference on systems sciences. p. 885-99.

Dunning, J. (1974). ed. The Multinational Enterprise, Allen and Unwin, London.

Faundez, J. \& Picciotto, S. (1978). Nationalization of Multinationals in peripheral Economies, Macmillan. Hong Kong.

Fons Trompenaars. (1998). Wave of Culture, Mc Grow Hill Press.

Freund, C.L. \& Weinhold D. (2002). The Internet and International Trade in Services. American Economic Review, 92(2): 236-240. doi:10.1257/000282802320189320, http://dx.doi.org/10.1257/000282802320189320

Freund, C.L. \& Weinhold, D. (2003). The Effect of the Internet on International Trade. Journal of International Economics, 62: 171-189. doi:10.1016/S0022-1996(03)00059-X, http://dx.doi.org/10.1016/S0022-1996(03)00059-X

GlobeScape Tectonics. (1998). Emerging Markets Directory-What Is An Emerging Market. http://members.aol.com/globescape/p10.htm, Nov 11, 1998.

Green, Duncan. (1995). Silent Revolution: The Rise of Market Economics in Latin America, London: Cassell.

Haughwout, Andrew F. (2001).Infrastructure and Social Welfare in Metropolitan America. Federal Reserve Bank of New York Economic Policy Review, 7,no.3, pp1-16.

Haughwout, Andrew F. (2002). Public Infrastructure Investments, Productivity, and Welfare in Fixed Geographic Areas, Journal of Public Economics, vol. 83, pp405-428. doi:10.1016/S0047-2727(00)00164-X, http://dx.doi.org/10.1016/S0047-2727(00)00164-X

Hickins, Michael. (1998). Reconcilable Differences. Journal of Management Review, vol.87, no.10, pp 54-58.

Hu, Zuliu \& Khan, Mohsin, S. (2007). Why is China Growing So Fast? International Monetary Fund.International Financial Statistic. International Monetary Fund (IMF) Bulletin, 2002-2007. 
Janaky. (1998). International Corporation, All about India. Big Emerging Markets, http://www.indiaintl.com/entry.html.

Jennings, Horace. (1994). Brazil: slowly emerging giant offers enormous potential'. Business America, 115(3), pp20-21.

Kellenberg, Derek K., (2003 a). The Provision of Public Inputs and Foreign Direct Investment. Working Paper (03)-11, University of Colorado.

Kellenberg, Derek. (2003b). U.S. Affiliates, Infrastructure and Growth: A Simultaneous Investigation of Critical Mass. Working Paper (03)-12, University of Colorado.

King and Flor. (2008). The development of global IT infrastructure. International journal of management Omega, 36, pp486 - 504. doi:10.1016/j.omega.2006.02.004, http://dx.doi.org/10.1016/j.omega.2006.02.004

Kwok \& Tadesse C.C.Y. Kwok \& S. Tadesse. (2006). The MNC as an agent of change for host-country institutions. FDI and corruption, Journal of International Business Studies, 27, pp767-785.

Lall, S. (1983).The Multinational Corporation, Macmillan, London.

Limao, Nuno \& Anthony J. Venables. (2001). Infrastructure, Geographical Disadvantage, Transport Costs, and Trade. The World Bank Economic Review, 15(3), pp1095-1111.

Martin.Philippe.( 1999). Public Policies, regional inequalities, and growth. Journal of Public Economics, 73, pp85-105.

Mckay. D. T. \& D. W. Brockway. (1989). Building IT infrastructure for the 1990s'. journal of Stage by Stage, 9( 31, pp1-11.

Muello, Peter. (1998). Support makes Brazil optimistic. Houston Chronicle.1.

Neghandhi, Anant, Peanut Philanthropy. (1985). Contributions Multinationals to Host Countries. Economies, in Japan's Emerging Multinationals. (Eds)., University of Tokyo Press, Tokyo.

Nijkamp,P. (2003). Entrepreneurship in a modern network economy: Debates and surveys' Regional studies, 37, pp395-405. doi:10.1080/0034340032000074424, http://dx.doi.org/10.1080/0034340032000074424

Prahalad, C.K., Lieberthal, Kenneth. (1998). The end of corporate imperialism. Harvard Business Review. pp. 69-79.

Rogers, E. (1995). Diffusion of Innovations, Free Press, New York, NY.

Roller, Lars-Hendrik, and Leonard Waverman. (2001). Telecommunications Infrastructure and Economic Development: A Simultaneous Approach. American Economic Review, vol.91,no.4, 909-923. doi:10.1257/aer.91.4.909, http://dx.doi.org/10.1257/aer.91.4.909

Sacks, Doug. (1998). Hot markets for Target Marketing,pp 64-71.

Takayama, M. (1985). Plan for Research, in Japan's Emerging Multinationals. S. Takamiya, and K. E. Thurley.(Eds.), University of Tokyo Press, Tokyo.

Thurley, K., Reitsperger, W., Trevor, M. \& Worm, P. (1980). The Development of Personnel in Japanese Enterprise in Great Britain. International Center for Economics and Related disciplines, London School of Economics, London.

U.S. Department of State. (1997-2007). Background Notes: Brazil. Bureau of Inter-American affairs. http://www.state.gov/www/background_notes/brazil_0997_bgn.html.

Wen Qu and Philomena Leung. (2006). Cultural impact on Chinese corporate disclosure - a corporate governance perspective. Managerial Auditing Journal,21(3). doi:10.1108/02686900610652991, http://dx.doi.org/10.1108/02686900610652991

Wilczynski, J. (1976). The multinationals and East-West relations: towards Tran ideological collaboration. London: Macmillan press.

World Bank (2007). China, India, \& Brazil at a Glance. http://www.worldbank.org.

Yang, John Z. (1998). Key Success Factors of Multinational Firms in China. Thunderbird International Business Review, 40(6), 633-668. doi:10.1002/(SICI)1520-6874(199811/12)40:6<633::AID-TIE7>3.0.CO;2-D, http://dx.doi.org/10.1002/(SICI)1520-6874(199811/12)40:6<633::AID-TIE7>3.0.CO;2-D

www.Press release.com. 
Table 1. IT infrastructure in Brazil 1997-2007(Per 100 people)

\begin{tabular}{|c|c|c|}
\hline Year & Fixed line and mobile phone subscribers & Internet Users \\
\hline 1997 & 13 & 1 \\
\hline 1998 & 16 & 1 \\
\hline 1999 & 23 & 2 \\
\hline 2000 & 31 & 3 \\
\hline 2001 & 37 & 5 \\
\hline 2002 & 41 & 8 \\
\hline 2003 & 47 & 10 \\
\hline 2004 & 57 & 12 \\
\hline 2005 & 67 & 17 \\
\hline 2006 & 73 & 23 \\
\hline 2007 & 84 & 26 \\
\hline
\end{tabular}

Adapted from World Development Indicator, 2007

Table 2. IT infrastructure in India 1997-2007(Per 100 people)

\begin{tabular}{|c|c|c|}
\hline Year & Fixed line and mobile phone subscribers & Internet Users \\
\hline 1997 & 2 & 0 \\
\hline 1998 & 2 & 0 \\
\hline 1999 & 3 & 0 \\
\hline 2000 & 4 & 1 \\
\hline 2001 & 4 & 1 \\
\hline 2002 & 5 & 2 \\
\hline 2003 & 7 & 2 \\
\hline 2004 & 9 & 3 \\
\hline 2005 & 13 & 5 \\
\hline 2006 & 19 & 11 \\
\hline 2007 & 24 & 18 \\
\hline
\end{tabular}

Adapted from World Development Indicator, 2007

Table 3. IT infrastructure in China 1997-2007(Per 100 people)

\begin{tabular}{|c|c|c|}
\hline Year & Fixed line and mobile phone subscribers & Internet Users \\
\hline 1997 & 7 & 0 \\
\hline 1998 & 9 & 0 \\
\hline 1999 & 12 & 1 \\
\hline 2000 & 18 & 2 \\
\hline 2001 & 26 & 3 \\
\hline 2002 & 33 & 5 \\
\hline 2003 & 41 & 6 \\
\hline 2004 & 50 & 7 \\
\hline 2005 & 57 & 9 \\
\hline 2006 & 63 & 10 \\
\hline 2007 & 69 & 16 \\
\hline
\end{tabular}

Adapted from World Development Indicator, 2007 